\title{
Bustan al-Salatin Panduan kepada Pemerintahan Islam yang Adil oleh Golongan Pembantu Raja \\ Bustan al-Salatin as a Guide to Justice of Islamic Government by King's Aides
}

\author{
NOR ASHIKIN BINTI MD NOR \\ SALMAH JAN BINTI NOOR MUHAMMAD
}

\author{
Jabatan Bahasa Melayu, Fakulti Bahasa Moden dan Komunikasi, \\ Universiti Putra Malaysia, 43400 Serdang, Selangor Darul Ehsan, Malaysia. \\ norashikin341@yahoo.com, salmahjannoor@gmail.com \\ Diterima: 18 Mei 2017 / Dibaiki: 25 Julai 2017
}

\begin{abstract}
Abstrak Konsep keadilan dalam Islam mempunyai pengertian yang luas dan mendalam. Keadilan dalam Islam mencakupi keseluruhan sudut kehidupan manusia tanpa sebarang pengecualian. Golongan raja atau pemerintah sering dikaitkan dengan konsep keadilan. Hal ini demikian kerana golongan ini memegang amanah dan tanggungjawab yang besar terhadap rakyat dan negara di bawah pemerintahannya. Namun begitu, konsep keadilan juga dianggap penting bagi golongan pembantu raja iaitu golongan kadi, wazir, utusan dan kahtib. Oleh itu, artikel ini akan membincangkan konsep keadilan Islam oleh golongan pembantu raja yang terdapat dalam naskhah Bustan al-Salatin di samping menganalisis implikasi amalan keadilan dalam sistem pemerintahan sesebuah kerajaan. Kajian ini akan menggunakan kaedah analisis teks dan kaedah kepustakaan. Selain itu, kajian ini akan menggunakan teori keadilan Islam oleh Majid Khadduri (1999). Menurut beliau, keadilan dalam Islam dapat dibahagikan kepada beberapa aspek, iaitu keadilan politik, keadilan teologi, keadilan falsafah, keadilan akhlak, keadilan undang-undang, keadilan antara bangsa dan keadilan sosial.
\end{abstract}

Kata kunci: Keadilan, Islam, raja, pembantu raja, naskhah Bustan al-Salatin.

Abstract The concept of justice in Islam has a broad and deep understanding. Justice in Islam embraces all aspects of human life without exception. The Kings or governments are often associated with the concept of justice. This is because these people hold the trust and great responsibility toward the people and the country under their rule. However, the concept of justice is also considered important for the king's aides, whom are the the viziers, messengers and scribes. This article discusses the concept of Islamic justice 
embraced by the king's aides as recorded in the Bustan al-Salatin and the implications of the practice of justice in the system of a government. This study employed the methods of textual and documentary analysis. In addition, this study incorporated the theory of Islamic justice by Majid Khadduri (1999). According to Majid Khadduri, the justice in Islam can be divided into several aspects, such as political justice, theological justice, philosophy of justice, morality justice, legal justice, justice between peoples, and social justice.

Keywords: Justice, Islam, king, king's aides, Bustan al-Salatin.

\section{PENGENALAN}

Setiap insan perlu berurusan dengan pelbagai lapisan masyarakat dengan adil dan saksama, tanpa mengira warna kulit, warganegara, status, atau kepercayaan. Islam mewajibkan umatnya supaya bersikap adil dalam semua keadaan. Ajaran ini menunjukkan keadilan Islam bukannya satu teori di awangan yang tidak berpijak di alam nyata, tetapi ia adalah perintah Allah SWT sebagaimana yang terkandung dalam firman Allah yang berbunyi;

"Wahai orang-orang yang beriman, hendaklah kamu semua sentiasa menjadi orang-orang yang menegakkan keadilan kerana Allah, lagi menerangkan kebenaran, dan jangan sekali-kali kebencian kamu terhadap sesuatu kaum itu mendorong kamu kepada tidak melakukan keadilan. Hendaklah kamu berlaku adil (kepada sesiapa jua) kerana sikap adil itu lebih hampir kepada taqwa dan bertaqwalah kepada Allah. Sesungguhnya Allah Maha Mengetahui dengan mendalam akan apa yang kamu lakukan.

(Surah al-Maidah: 8)

Menurut perspektif Islam, hal keadilan ini sangat penting kerana pelaksanaan keadilan dalam negara merupakan perkara besar yang ditanggung oleh ketua, sama ada raja atau pemimpin. Penekanan Islam terhadap konsep keadilan dapat dilihat menerusi ayat-ayat al-Quran dan hadis yang menerangkan tentang sifat adil dan perkara-perkara yang berhubung dengannya. Penganjuran untuk membudayakan konsep keadilan 
dalam kehidupan terdapat dalam beberapa surah al-Quran mahupun hadis. Umpamanya dalam Surah al-Nahl ayat 90 yang bermaksud;

"Sesungguhnya Allah menyuruh kamu berlaku adil dan berbuat kebajikan, memberi kepada kaum kerabat, dan Allah melarang dari perbuatan keji, kemungkaran dan permusuhan. Dia memberi pengajaran kepada kamu supaya kamu dapat mengambil pengajaran."

Menegakkan keadilan di muka bumi ini menjadi tuntutan ke atas setiap individu Muslim. Tuntutan untuk menegakkan keadilan dalam masyarakat tidak seharusnya diabaikan, sebagaimana Islam itu sendiri yang sentiasa segar merentasi zaman. Nabi Muhammad SAW yang dianugerahi nilai keadilan dalam dirinya telah melalui zaman kezaliman dan penganiayaan yang meluas dalam masyarakat tempatan Baginda dibesarkan.

Pada zaman Kesultanan Melayu, konsep keadilan sering dikaitkan dengan sistem pemerintahan sesebuah kerajaan. Jelani Harun (2001: 133) menyatakan bahawa dalam Islam, panduan kepada raja-raja supaya melaksanakan keadilan bukan sahaja dinyatakan dalam ajaran agama, malah diolah secara lebih kreatif menerusi karya kesusasteraan yang lebih dikenali sebagai karya ketatanegaraan. Misalnya Bustan al-Salatin hasil nukilan Nurudddin ar-Raniri. Penulisan naskhah ini bertujuan untuk memberi panduan dan pedoman kepada raja dan pembesar tentang aspek kepemimpinan, khususnya dalam membentuk pemimpin yang adil. Keadilan dalam Islam tidak terbatas kepada golongan tertentu sahaja misalnya golongan raja atau pemimpin, sebaliknya sifat keadilan haruslah ditanamkan dalam diri setiap individu. Dalam sistem pemerintahan sesebuah kerajaan, konsep keadilan bukan sahaja perlu diamalkan oleh golongan raja, malahan sikap ini perlu diamalkan oleh golongan pembantu raja. Golongan pembantu raja terdiri daripada golongan kadi, wazir, utusan dan kahtib.

Bantuan terpenting daripada golongan pembantu raja atau golongan pentadbir yang diperlukan oleh golongan penguasa atau raja wujud dalam istilah yang dipanggil wazir atau menteri. Wazir atau menteri merupakan bantuan terpenting daripada golongan yang diperlukan oleh golongan penguasa atau raja dalam urusan pentadbiran negara. Menurut catatan Ibnu Khaldun, wazir merupakan tonggak kepada fungsi pemerintahan 
dan mempunyai kedudukan yang tinggi dalam sistem kerajaan. Secara ringkasnya, istilah 'wazir' sendiri bererti 'pertolongan'. Di samping itu, menurut catatan Al-Mawardi perkataan Wazir diambil daripada kata dasar Al- Azr yang membawa maksud 'belakang' kerana para pemerintah mendapat kekuatan daripada Wazirnya sebagaimana tubuh badan mendapat kekuatan dari 'belakang'. Golongan pentadbir pula merupakan pembantu yang menjalankan urusan pentadbiran negeri dan memerlukan kebolehan khusus dalam bidang yang diamanahkan kepada mereka (Muzaffar Mohamad: 53).

\section{Makna keadilan}

Setiap aspek dari keadilan terdapat beberapa kata dan yang paling umum digunakan adalah kata 'adl'. Seterusnya, terdapat beberapa sinonim dan yang terpenting ialah seperti berikut; qisr, qasd, istiqamah, wasaw, nasib, hissah, mizan dan lain-lain lagi. Perkataan antonim bagi 'adl bukanlah muncul hasil daripada pengubahsuaian ejaan perkataan ' $a d l$ itu, yang membayangkan pengertian negatifnya. Misalnya dalam bahasa Inggeris perkataan lawan bagi "justice" ialah "injustice". Tetapi dalam bahasa Arab, perkataan antonim bagi 'adl ialah jawr. Perkataan jawr juga mempunyai beberapa perkataan sinonim. Antaranya yang banyak perbezaan kecil pada maknanya. Misalnya, perkataan zulm (kezaliman), tughya (penganiayaan), mayl (kecenderungan), inhiraf (penyimpangan) dan lain-lain lagi (Majid Khadduri, 1999: 7)

Secara harfiah, kata ' $a d l$ adalah kata benda abstrak, berasal daripada kata 'adalah yang bererti pertama, meluruskan atau duduk lurus, mengubah; kedua, melarikan diri, berangkat atau mengelak dari satu jalan yang keliru menuju ke jalan yang benar; ketiga, sama atau sepadan atau menyamakan; keempat menyeimbangkan atau mengimbangi, sebanding atau berada dalam keadaan yang seimbang. Akhirnya kata 'adl atau idl boleh juga bererti contoh atau semisal, sebuah ungkapan harfiah yang secara tidak langsung berhubungan dengan keadilan (Majid Khadduri, 1999: 7).

Dari segi konsep, Ibn Manzur, seorang ahli leksikografi menjelaskan bahawa yang dimaksudkan dengan keadilan ialah sesuatu yang sudah 
mantap dalam fikiran sebagai perkara yang lurus (1845: 153). Sesuatu yang bengkok atau tidak berada dalam kedudukannya yang betul disebut jawr atau tidak adil. Pengertian harafiah bagi perkataan 'lurus' dan 'menyimpang' dibayangkan dalam konsep kelurusan, manakala kefahaman tentang 'benar' dan 'salah' dibayangkan dalam isitlah 'adl dan jawr. Istilah ini digunakan secara meluas serta merangkumi nilai moral dan agama. Konsep 'adl, sebagai 'benar', setara dengan konsep keadilan dan kesaksamaan dan lebih tepat lagi jika ia dinyatakan dalam istilah istiqamah atau lurus (Majid Khadduri, 1999: 8).

Kesimpulannya, sifat adil wajib dimiliki oleh setiap manusia terutama dalam hubungan sesama mereka kerana setiap individu sebenarnya sudah terletak suatu tanggungjawab semula jadi yang wajib ditunaikan dengan cara adil dan saksama. Ia adalah antara kebesaran Islam bagi menjamin hak manusia supaya hidup dalam keadaan aman dan damai (Idris Zakaria, 2014: 51).

\section{KAJIAN LEPAS}

Bustan al-Salatin merupakan sebuah karya ketatanegaraan dalam perbendaharaan Kesusasteraan Melayu tradisional. Karya yang dikarang oleh Nuruddin al-Raniri ini memberi panduan tentang tatacara pemerintahan kepada raja dan pembesar. Disebabkan naskhah Bustan al-Salatin tersebut merupakan antara karya ketatanegaraan yang pernah dihasilkan dalam Kesusasteraan Melayu tradisional, maka ramai pengkaji yang cuba untuk menilai dan meneliti serta mentafsir buah tangan Nuruddin al-Raniri tersebut.

Pada tahun 2002, Aidil Farina bt. Omar mengkaji metodologi penulisan al-Raniri dalam naskhah Bustan al-Salatin ini dengan membandingkannya dengan kitab Tarikh al-Rusul Wa al-Muluk karya al-Tabari untuk melihat sejauh mana beliau terpengaruh dengan metodologi penulisan ahli-ahli sejarah Islam yang terdahulu. Kajian peringkat sarjana di Universiti Islam Antarabangsa Malaysia ini berjudul Shaykh Nur al-Din al-Raniri: A Study of His Career \& Magnum Opus Bustan al-Salatin. Walaupun begitu, kajian ini hanya membincangkan tentang pengaruh dan pemikiran dalam keduadua kitab tersebut tanpa membuat perbandingan dengan kitab penasihatan khalifah yang lain. 
Seterusnya ialah Abdullah Sani Usman (2005) telah membuat kajian perbandingan antara Bustan al-Salatin dengan Kanun Syarak Kerajaan Acheh untuk melihat nilai sastera ketatanegaraan dan undang-undang yang terdapat dalam kedua-dua karya ini. Buku yang bertajuk Pemikiran Adab Ketatanegaraan Kesultanan Melayu (2003) yang telah ditulis oleh Jelani Harun pula secara umumnya membincangkan tentang sastera adab ketatanegaraan yang wujud dalam rumpun Melayu dari dahulu hinggalah sekarang. Ia termasuklah Taj al-Salatin dan Bustan al-Salatin.

Selain itu, kajian tentang transliterasi dan kajian pustaka Melayu dalam Bustan al-Salatin telah dilakukan oleh Salmah Jan binti Noor Muhammad (2006). Kajian tersebut dilaksanakan untuk mentransliterasikan secara keseluruhan naskhah Bustan al-Salatin: Bab Tujuh yang bertulisan jawi dipindahkan ke dalam tulisan rumi bagi memudahkan proses pemahaman serta dapat mengetengahkan naskhah ini kepada khalayak. Kajian ini juga menghuraikan himpunan pustaka Melayu yang terdapat dalam naskhah Bustan al-Salatin. Hasil kajian telah menemukan tiga cabang ilmu yang paling dominan dan dianggap penting dalam masyarakat silam iaitu ilmu perubatan, ilmu firasat dan ilmu perkahwinan.

Kajian tentang keadilan pula telah dilakukan oleh Muhd Norizam Jamian dan Mohd Yuszaidy Mohd Yusoff (2017) dalam makalah yang bertajuk "Keadilan Teras Kepimpinan Raja-raja Melayu: Dari Era Tradisi ke Kontemporari". Kajian ini meliputi karya-karya ketatanegaraan Melayu tradisional iaitu Taj al-Salatin, Bustan al-Salatin, Kitab Nasihat Raja-raja dan Thamarat al-Muhimmah dengan mengaplikasikan pendekatan adab berasaskan model kerangka pemikiran Syed Muhammad Naquib al-Attas (2001). Namun begitu, kajian-kajian tersebut tidak menyentuh tentang konsep keadilan oleh golongan pembantu raja iaitu wazir, dan kadi seperti yang akan dilakukan oleh penulis. 


\section{OBJEKTIF KAJIAN}

Objektif kajian ini ialah mengkaji konsep keadilan Islam oleh golongan pembantu raja seperti yang terdapat dalam naskhah Bustan al-Salatin hasil nukilan Nuruddin ar-Raniri. Selain itu, kajian ini akan menganalisis sifatsifat keadilan yang dipamerkan oleh golongan pembantu raja iaitu wazir dan kadi dalam naskhah Bustan al-Salatin Bab Ketiga fasal yang kedua, di samping menganalisis implikasi amalan keadilan dalam sistem pemerintahan sesebuah kerajaan.

\section{METODOLOGI}

Kajian ini menggunakan teori keadilan Islam oleh Majid Khadduri (1999). Teori keadilan yang diperkenalkan oleh Majid Khadduri ini dipilih bagi memahami dengan lebih lanjut tentang konsep keadilan yang terdapat dalam analisis kajian. Majid Khadduri (1999: 15) telah mengklasifikasikan keadilan kepada beberapa bahagian iaitu keadilan politik, keadilan teologi, keadilan falsafah, keadilan akhlak, keadilan undang-undang, keadilan di antara bangsa dan keadilan sosial. Menurut beliau, aspek yang paling mempengaruhi keadilan melibatkan bidang politik dan undang-undang. Walau bagaimanapun, aspek lain juga saling berkaitan dan bertanggungjawab menentukan peringkat yang berubah-ubah dalam kehidupan umat Islam buat beberapa abad lamanya. Kajian ini akan menyentuh beberapa aspek keadilan yang sesuai dengan tema kajian, iaitu aspek keadilan undangundang, keadilan sosial dan keadilan akhlak. 


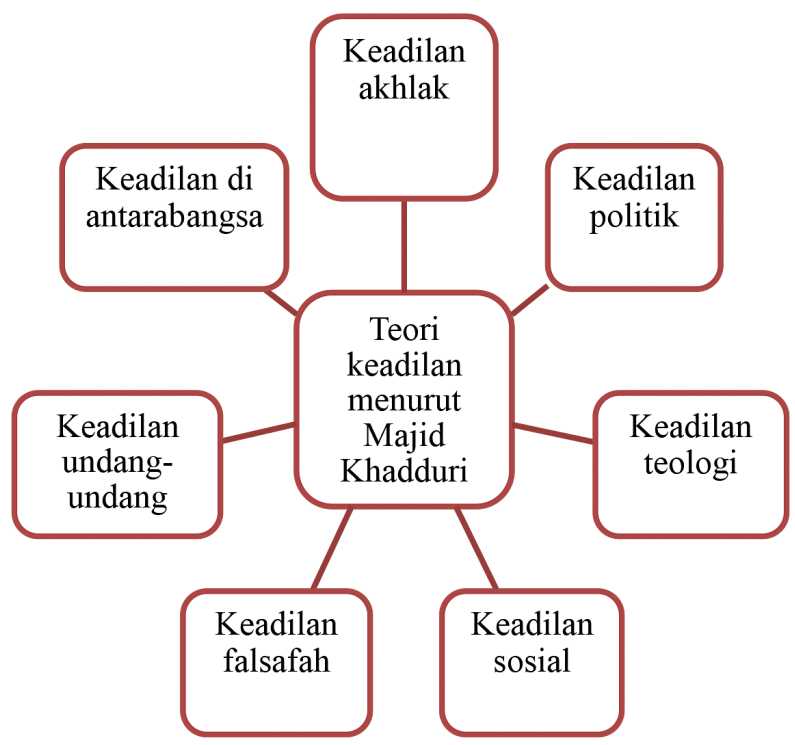

RAJAH 1 Teori keadilan menurut Majid Khadduri

Sumber: Teologi Keadilan Perspektif Islam, hlm 15.

\section{Latar Belakang Naskhah Bustan al-Salatin}

Bustan al-Salatin dikarang khas oleh Nuruddin al- Raniri atas permintaan Sultan Iskandar Thani yang digelar Sultan Iskandar Thani Alauddin Mughayat Syah Johan Berdaulat zillullah fil alam pada tahun 1638. Nuruddin al-Raniri merupakan seorang ulama, pengarang, ahli tasawuf dan ahli sejarah yang berasal dari Rander, Gujerat, India. Beliau tiba di Aceh sekitar tahun 1637 dan dilantik sebagai penasihat di istana Aceh oleh Sultan Iskandar Thani. Bustan al-Salatin (kebun atau taman raja-raja) merupakan karya Nuruddin yang keempat daripada sembilan karyanya. Naskhah tersebut secara umumnya memperkatakan tentang panduan dan nasihat adab pemerintahan kepada raja-raja Aceh berteraskan kerangka keislaman. Beliau telah menjadikan al-Quran, al-Hadis dan kitab-kitab yang ditulis oleh para ulama silam sebagai sumber rujukan. Oleh itu, nilai ilmiah naskhah tersebut sangat tinggi kerana rujukan yang dilakukan oleh mereka membuktikan bahawa fakta-fakta yang dipaparkan telah diperakui kebenarannya. Tambahan pula, al-Quran dan al-Hadis adalah sumber hukum dan panduan hidup tertinggi bagi umat Islam. 
Bustan al-Salatin memancarkan idealisme pengarangnya, iaitu Nuruddin al-Raniri dalam memaparkan dimensi pemikirannya yang khusus mengenai adab pemerintahan. Idealisme dan falsafah pemikiran yang terkandung dalam teks tersebut dapat dilihat dalam setiap bab yang terkandung di dalamnya. Kitab tersebut mengandungi tujuh bab dan terbahagi kepada 60 fasal:

Bab 1: Pada menyatakan kejadian bumi tujuh petala langit. (30 fasal)

Bab 2: Pada menyatakan segala anbia dan raja-raja. (13 fasal)

Bab 3: Pada menyatakan raja-raja yang adil, kadi, wazir, utusan dan katib. (6 fasal)

Bab 4: Pada menyatakan raja-raja yang pertapa dan segala anbia yang salih. (2 fasal)

Bab 5: Pada menyatakan kelakuan raja yang zalim dan wazir yang aniaya. (2 fasal)

Bab 6: Pada menyatakan orang yang sakhi (pemurah) dan orang yang berani. (2 fasal)

Bab 7: Pada menyatakan akal dan ilmu, firasat, penyakit, dan ilmu tabib, sifat perempuan dan cerita-cerita ajaib. (5 fasal)

Naskhah tersebut memperlihatkan ciri karya ketatanegaraan yang istimewa dan tersendiri kerana ia merupakan satu-satunya karya dalam khazanah kesusasteraan Melayu yang memiliki gabungan ciri genre Sejarah Dunia dan Sastera Adab (Jelani Harun, 2003). Kajian ini tertumpu kepada bab ketiga naskhah Bustan al-Salatin yang menceritakan tentang rajaraja yang adil dan menteri yang bijaksana. Bab ketiga merupakan salah satu bab yang sangat penting dalam keseluruhan teks Bustan al-Salatin, yakni bab khusus yang membicarakan persoalan keadilan raja dan para pembesar negara. Penulisan bab tersebut menggambarkan beberapa konsep asas Nuruddin ar-Raniri tentang kewajipan dan tanggungjawab raja-raja, 
khususnya dilihat dari sudut keagamaan. Beliau turut membicarakan tentang beberapa peraturan dan sifat-sifat yang perlu dimiliki oleh raja dan para pembesar negara, khususnya yang berteraskan prinsip keadilan kepada rakyat (Jelani Harun, 2008: xxxiii). Justeru, pengkaji memilih Bab Ketiga Bustan al-Salatin sebagai landasan kajian.

\section{ANALISIS KAJIAN}

Terdapat banyak versi penulisan naskhah Bustan al-Salatin. Namun, kajian ini akan menggunakan naskhah Bustan al-Salatin yang diselenggarakan oleh Jelani Harun pada Tuhan 2008. Bagi meneliti konsep keadilan Islam oleh golongan pembantu raja yang terdapat dalam naskhah Bustan al-Salatin, fokus penelitian tertumpu kepada Bab Ketiga Fasal Kedua, iaitu "pada menyatakan raja-raja yang adil, kadi, wazir, utusan dan katib". Hasil daripada analisis yang dilakukan terhadap naskhah ini dengan menggunakan konsep keadilan menurut Majid al-Khadduri, didapati pengarang mengetengahkan konsep keadilan seperti keadilan undang-undang, keadilan sosial, serta keadilan akhlak.

\section{Keadilan Undang-undang}

Keadilan undang-undang bermakna keadilan yang selaras dengan undangundang. Dari segi etimologi, keadilan ialah satu istilah undang-undang di mana literal jus (hukum) dan justum adalah saling bertindih. Walau bagaimanapun, makna keadilan undang-undang telah diperluaskan bagi menggambarkan aspek-aspek lain (Majid Khadduri, 1999: 165). Justeru, undang-undang dan keadilan saling berkait kerana undang-undang menjadikan keadilan sebagai salah satu objektifnya. Sementara itu, aspek undang-undang dalam karya ketatanegaraan iaitu Bustan al-Salatin boleh diteliti dalam konteks yang luas atau pun khusus. Pengarang memberikan tumpuan kepada raja-raja dan pembantu raja yang meneraju pemerintahan negara supaya melaksanakan keadilan. Apabila golongan pemerintah berpegang kepada prinsip etika keadilan, maka dengan sendirinya segala urusan negara serta rakyat akan berjalan pada landasan yang sepatutnya termasuk dalam pelaksanaan undang-undang. 
Dalam perspektif ini, pengarang Bustan al-Salatin memaparkan fasal yang khusus tentang konsep keadilan yang harus diamalkan oleh golongan raja dan pembantu raja dalam melaksanakan pemerintahan sesebuah negara. Namun begitu, tumpuan pengarang bukan terhadap pembentukan undangundang atau menentukan hukum-hakam tetapi lebih kepada etika pelaksanaan undang-undang. Antara lain naskhah ini lebih menitikberatkan sifat-sifat golongan pelaksana hukum yang baik dan adil dalam memberi hukuman atau memelihara kesejahteraan rakyat. Selain itu, etika golongan tersebut tidak hanya dibuat dalam bentuk senarai peraturan dan syarat-syarat yang lebih formal, tetapi diolah secara kreatif berdasarkan cerita-cerita teladan. Cerita-cerita berkenaan bersumberkan pelbagai koleksi cerita adab tulisan para ilmuwan dan ulama masa silam. Ia meliputi pelbagai kisah tentang raja, pembesar, dan sebagainya. Walaupun segala cerita berkenaan telah berlaku pada zaman silam tetapi ia mengandungi hikmah dan iktibar yang masih relevan dalam pembentukan etika golongan pemerintah termasuklah golongan pembantu istana hingga kini. Bab Ketiga dalam naskhah Bustan al-Salatin mengetengahkan tema berkaitan keadilan raja dan golongan pembantu raja dalam urusan pentadbiran. Dari sudut perbincangan, pengkajian ini melihat aspek pelaksanaan undang-undang yang dijalankan secara adil berdasarkan naskhah Bustan al-Salatin. Hal ini dapat dilihat melalui peristiwa tersebut;

Kata kadi Abu Yusuf rahmatullah, iaitu kadi Raja Harun al-Rasyid, "Pada suatu hari, datang kepadaku seorang laki-laki Majusi mendakwa harta kepada Yahya Barmaki, serta hadir keduanya berdakwa. Maka kuminta saksi kepada Majusi. Maka sahutnya, "Tiada saksi kepada hamba". Maka kusuruh akan Yahya bersumpah, maka ia bersumpahlah, serta redalah keduanya akan hukumku itu dan adalah kusamakan hukum antara Yahya dan Majusi, tiada lagi segala hatiku cenderung memenangkan seorang akan seorang, kerana takut aku lagi akan ditanyai Allah Taala daripada segala barang yang kuhukumkan.

(Jelani Harun, 2008: 208)

Berdasarkan petikan di atas, jelas bahawa keadilan dalam pelaksanaan undang-undang yang dipamerkan oleh watak kadi Raja Harun al-Rasyid iaitu kadi Yusuf rahmatullah adalah bertepatan dengan konsep keadilan undang-undang oleh Majid Khadduri. Menurut Majid Khadduri (1999: 199), pelaksanaan hukum dalam Islam sangat berkait rapat dengan agama 
dan keduanya dianggap sebagai pernyataan dari kehendak Allah SWT dan keadilan, tetapi sebaliknya tujuan agama adalah untuk menentukan tujuan-tujuan keadilan dan lain-lain, sementara fungsi hukum adalah sebagai jalan berdasarkan atas keadilan Allah SWT. Melalui peristiwa di atas, jelas menunjukkan Kadi Yusuf meminta saksi sebagai cara untuk menentukan pemilikan harta dan jika tiada saksi maka Yahya dan Majusi disuruh bersumpah. Menurut Majid Khadduri (1991: 201) syarat minimum adalah ia harus memperlihatkan pada waktu kesaksiannya diberikan. Kadi Yusuf berlaku adil dengan menyuruh kedua-duanya melakukan perkara yang sama iaitu dengan bersumpah kerana kedua-duanya tidak mempunyai saksi untuk membuktikan pemilikan harta tersebut.

Menerusi naskhah Bustan al-Salatin, Nuruddin ar-Raniri menegaskan bahawa raja haruslah melantik kadi berdasarkan beberapa syarat, iaitu Islam, aqil, merdeka, lelaki, adil, sempurna penglihatan, sempurna tutur kata dan mujahid (Bustan al-Salatin: 207). Oleh itu, seorang kadi haruslah menjalankan tugas dengan adil kerana golongan ini memikul amanah yang sangat besar. Raja bertanggungjawab melantik kadi yang adil bagi menguruskan persoalan kehakiman dan undang-undang dalam negeri. Perkara ini dibicarakan dengan lebih lanjut oleh Nuruddin ar-Raniri dengan mengemukakan pandangan dalam naskhah Bustan al-Salatin;

Seyogianya bagi segala kadi menghukumkan dengan hukum yang sebenar kerana jika ia hukum dengan tiada sebenar maka jadi ia makzul, tiada sah hukumnya lagi, dan apabila ia menghukumkan dengan sebenarnya nescaya diperolehnya pahala dalam dunia dan akhirat dengan pahala yang amat besar seperti sabda Nabi sallallahu alaihi wasallam: Liajri muhakimu'l-muslimati fi yaumi wa ahda afdhala min ayyu wakallu wasolla baiti arba'ina sittah. Ertinya: Pahala kadi yang menghukumkan dengan hukum yang adil pada sehari terafdal daripada seorang yang sembahyang dalam rumahnya tujuh puluh tahun.

(Jelani Harun, 2008: 497)

Kisah yang telah dinyatakan berkait rapat dengan pemerian teks yang telah dibicarakan di atas. Huraian Nuruddin ar-Raniri tentang ganjaran yang diperoleh oleh kadi yang adil merupakan suatu dasar penting yang perlu diketahui oleh setiap golongan kadi. Mereka perlu memahami tugas dan 
amanah yang telah dipertanggungjawabkan sebagai golongan pemerintah dan kadi dalam menguruskan pentadbiran sesebuah negara. Ganjaran pahala dan syurga akan menanti para kadi yang adil dan menjalankan amanah dengan baik. Bagi kadi yang gagal melaksanakan tanggungjawabnya pula, dia akan menerima dosa dan neraka menantinya seperti yang dijelaskan dalam petikan berikut;

Kata sahibulhikayat, tatkala Abbas anak Muawiyah jadi kadi, maka datang kepadanya Syeikh Abu Hassan al-Basri radiallahuanhu. Maka dilihatnya akan Abbas terlalu sangat dukacitanya serta dengan tangisnya. Maka kata Syeikh Hassan al-Basri akan dia, "Ngapa maka tuan hamba menangis?" Maka sahutnya, "Ya syeikh, terlebih hamba dengar suatu sabda Nabi sallallahu alaihi wasallam: 'l-quddat thalathatun, qadiyan fi 'l-nar wa qadin fi'l jannah. Qadin qada bi ghar haqqin wa huwa ya' 'lamu fa fa' ahlaka huquq 'l-nar fa dhalika fi 'l-nar, wa qadin qada bi haqqin fa dhalika fi 'l-jannah. Ertinya: segala kadi itu tiga bangsa, dua bangsa daripadanya masuk neraka, dan sebangsa daripada ia masuk syurga: Pertama-tama kadi yang menghukumkan dengan tiada sebenarnya dengan pengetahuannya maka iaitu masuk neraka, dan yang kedua kadi yang menghukumkan serta dengan tiada pengetahuannya maka dibinasakan hak manusia maka iaitu masuk neraka, ketiga daripadanya kadi yang menghukumkan dengan sebenarnya maka iaitulah masuk syurga."

(Jelani Harun, 2008: 497)

Apabila seseorang hamba Allah jadi kadi maka hendaklah ia menghukumkan dengan hukum yang lagi pada syarak dan jangan ia menghukumkan dengan hukum adat, maka jika ia hukum dengan kain daripada hukum Allah, maka ialah celaka seperti firman Allah [al-Ma'idah:44]:

Ertinya: Barang siapa tiada menghukumkan dengan barang yang diturunkan Allah Taala maka segala mereka itulah kafir.

Dan seperti sabda Nabi sallallahu wasallam: Man hajama baina'lkjatiru bi dhulm fa' alaih la'nat'l-Lah. Ertinya: Barang siapa hukum antara dua orang berdakwa dengan hukum yang aniaya maka dirimu dari kena bahaya. Hubaya-hubaya, jangan kamu menghukumkan antara manusia melainkan dengan hukuman yang sebenarnya jua.

(Jelani Harun, 2008: 502 - 501) 
Petikan tersebut menjelaskan bahawa golongan-golongan kadi yang akan masuk syurga atau neraka. Golongan kadi yang menjalankan tanggungjawabnya dengan adil dan menlaksanakan sistem perundangan dengan menjatuhkan hukuman dengan adil akan dijanjikan Allah SWT ganjaran syurga. Sementara itu, di sebalik hikmah yang Allah SWT janjikan kepada gologan kadi yang bertanggungjawab dan adil, pastinya Allah SWT membalas dengan balasan dosa dan azab neraka yang akan menanti golongan kadi yang tidak berlaku adil dan tidak bertanggungjawab dalam memberi hukuman ke atas rakyat. Dalam konteks ini, prinsip keadilan undang-undang yang terdapat dalam naskhah Bustan al-Salatin adalah berteraskan idealisme keadilan dalam ajaran Islam.

\section{Keadilan Sosial}

Keadilan sosial ialah keadilan yang berdasarkan norma dan nilai operatif, selain norma dan nilai yang terkandung dalam Syari'ah yang orang awam bersedia untuk menerimanya sebagai kebiasaan, sifat semula jadi atau sebab-sebab lain (Majid Khadduri, 1999: 214). Syed Quth menulis di dalam bukunya al-Adalah ai-Ijtima'iyyah fi al-Islam berkata:

"Kita tidak akan dapat memahami pengertian keadilan sosial dalam Islam secara tepat kecuali apabila kita memahami tasawur Islam tentang ketuhanan, alam sejagat, kehidupan dan manusia. Kerana keadilan sosial adalah satu cabang yang kecil daripada empat komponen induk tersebut".

(Syed Qutub, 1983: 20)

Kenyataan tersebut menyatakan bahawa keadilan sosial dalam Islam mestilah diikat dan dikaitkan dengan konsep akidah dan keimanan yang mendalam kepada ketauhidan Allah SWT serta tugas manusia sebagai khalifah Allah SWT di atas muka bumi ini iaitu sebagai agen pembangunan jasmani dan rohani. Konsep ketauhidan Allah SWT mempengaruhi keadilan sosial dalam Islam. Pandangan Islam terhadap kehidupan manusia di dunia ini sangat berkait rapat dengan keadilan sosial yang bererti keadilan manusia dalam segenap bidang kehidupan yang diceburi. Ia tidak terbatas kepada 'material' dan ekonomi sahaja, sebaliknya merangkumi nilai-nilai spiritual. Oleh itu, keadilan sosial merangkumi kehidupan kebendaan dan kerohanian. 
Keadilan sosial tidak akan wujud dalam sesebuah masyarakat sekiranya golongan yang tidak bernasib baik tidak dipelihara. Walaupun golongan ini akan tetap wujud dalam masyarakat, keadilan sosial akan tercapai sekiranya golongan berkemampuan bersama-sama bertanggungjawab menjaga kebajikan golongan tersebut. Kenyataan ini dapat kita hayati berdasarkan petikan yang terdapat dalam naskhah Bustan al-Salatin Bab Ketiga yang menceritakan seorang wazir yang berbuat kebajikan ke atas golongan rakyat dengan menyampaikan kehendak golongan tersebut kepada raja.

Sekali peristiwa, pada suatu hari, datang seorang laki-laki kepada syeikh itu yang tiada dipersembahkannya kepada raja ['Adhud alAdilat?] di negeri [Syairan?] kerana ada suatu hajat kesukarannya. Demi didengar syeikh kata laki-laki itu. Maka tiada didapati syeikh kata laki-laki itu, maka ia pun pergilah mengadap, maka tiada juga ia bertemu dengan raja. Demikianlah hal syeikh itu berulang hingga empat puluh kali pergi datang, tiadā ia bertemu dengan raja.

Kalakian ada seorang menteri raja itu mengetahui akan halnya yang demikian itu. Maka menteri itu pun pergi mengadap raja serta ia berdatang sembah, "Ya tuanku Syah Alam, bahawasanya Syeikh Jalal al-Din empat puluh kali ia datang kerana/ hendak mengadap dipersembahkan hajat laki- laki si polan." Setelah itupun, maka Syeikh Jalal al-Din datang mengadap raja. Demi dilihat raja akan syeikh itu, serta ia bersabda, "Ya tuan syeikh, ada hamba dengar bahawa tuan hamba berapa kali berulang datang kepada hamba kerana hendak menyampaikan hajat si polan itu dengan sekian kali tuan hamba. Apa jua hajatnya itu?" Maka semabah tuan syeikh, "Ya Tuanku Syah Alam, bahawa dipelelahkan [hamba] berulang-ulang itu pun kerana menghasilkan pekerjaan dan pahala bagi kesempurnaan Syah alam jua. Bahawasanya Allah Taala menganugerahi kebesaran dan kemuliaan dan kuasa, dapat Syah Alam memenuhi hajat seorang hamba Allah, jikalau tiada dipenuhi tuan hamba hajat seorang, nescaya hajat tuan hamba pun tiada dipenuhi Allah Taala, dan dijadikan-Nya tuan hamba muhtaj kepada orang yang lain daripada tuan hamba." [Apabila didengar] raja sembah syeikh demikian itu, maka ia pun menangis dan pekerjaan laki-laki itu dipenuhinyalah seperti kehendaknya.

(Jelani Harun, 2008: 527-528) 
Peristiwa tersebut menceritakan seorang menteri yang membantu seorang syeikh untuk bertemu dengan raja. Apabila menteri tersebut mengetahui bahawa seorang syeikh telah 40 kali berulang-alik untuk bertemu dengan raja bagi menyampaikan hajat seorang lelaki, menteri tersebut bertemu dengan raja untuk menyampaikan hajatnya. Menteri tersebut telah menjaga kebajikan rakyatnya dengan memenuhi kehendak rakyatnya yang tiada kuasa untuk bertemu dengan raja. Ibnu Tamiyah berpendapat bahawa keadilan sosial dapat merapatkan jurang pemisah antara golongan penguasa dan rakyatnya (ar-Rawi wa ar-Ra 'iyah) dan akhirnya dapat meningkatkan sistem sosial dan mempertinggikan kekuasaan Islam (Majid Khadduri, 1999: 265). Oleh itu, menjadi tanggungjawab seseorang wazir atau pembantu raja dalam menjaga kebajikan sosial sesebuah masyarakat. Seperti firman Allah SWT yang tersebut dalam Surah al-Qasas, ayat 77:

Ertinya: Perbuat olehmu kebajikan kepada segala hamba Allah seperti dianugerahi Allah Taala akan dikau kebajikan.

Yakni: Jikalau dijadikan Allah Taala raja, maka hendaklah ia memelihara akan segala rakyatnya, dan jika ada ia alim, maka hendaklah ia mengajarkan ilmunya/ akan segala hamba Allah, dan jika ada ia kaya, maka hendaklah hartanya akan degala fakir dan barang siapa kiranya.

Dan seperti sabda Nabi sallallahu alaihi wasallam:

Ertinya: Sampaikanlah oleh kamu hajat barang siapa yang tiada kuasa menyampaikan hajatnya itu, maka barang siapa menyampaikan kepada raja-raja hajat barang siapa yang tiada kuasa kepada raja-raja itu maka ditetapkan Allah Taala kedua tapak kakinya atas titi siratulmustakim pada Hari Kiamat.

(Jelani Harun, 2008: 528-529)

Naskhah Bustan al-Salatin Bab Ketiga fasal kedua turut menyatakan syarat ke-11 untuk menjadi seorang wazir;

Syarat kesebelas, hendaklah wazir itu sentiasa/mencari kebajikan rajanya dalam pekerjaan dunia dan miskin supaya doa mereka itu jadi bertambah-tambahlah saadat dan daulat rajanya. Dan hendaklah ia 
memohonkan segala yang berdosa kepada rajanya dan jangan suatu katanyaa yang tiada patut disampaikannya kepada rajanya.

(Jelani Harun, 2008: 540)

Petikan ini menunjukkan bahawa seseorang wazir itu hendaklah mencari kebaikan yang terdapat dalam diri rajanya. Hal ini dapat meningkatkan kebahagiaan dan kedaulatan rajanya kerana raja yang baik akan sentiasa didoakan oleh rakyatnya. Wazir juga perlu bijak dalam memastikan setiap perkara yang diketahui oleh raja adalah positif walaupun hakikatnya perkara tersebut boleh mengundang dosa atau kemurkaan raja. Kenyataan ini dapat dilihat menerusi peristiwa tersebut;

Seperti kata sahibul hikayat, ada seorang raja pada zaman dahulukala di benua Parsi, ditawannya akan seorang laki-laki, maka dititahkannya bunuh akan laki-laki itu. Lalu dibawa oranglah akan dia. Maka ia pun putus asalah daripada hidup. Maka sakitlah hatinya. Tatkala dibawa orang akan dia lalu disumpahnya akan raja itu dengan nyaring suaranya.

Ertinya: Apabila putus kata manusia daripada hidup maka terlanjurlah perkataan lidahnya, seperti musang, apabila ia kepijakkanlah maka dilawannyalah akan anjing.

Syahadan maka raja itu pun bersabda kepada segala menterinya, "Hai segala menteriku, apa kata laki-laki itu?" Maka berdatang seorang perdana menterinya yang bijaksana, "Ya Tuanku Syah Alam, bahawa laki-laki itu membaca ayat ini (Ali-'Imran: 134):

Ertinya: Segala mereka yang menahan amarah dan memaafkan daripada kesalahan manusia, bermula Allah Taala juga mengasihi segala yang berbuat kebajikan.

Demi didengar raja sembah menteri itu demikian, maka ia pun berkasihanlah hatinya akan dia lalu diampunnya akan laki-laki itu. Maka berdatang sembah seorang wazirnya yang adawat dengan perdana menteri itu, "Ya Tuanku Syah Alam, sama kami menteri, tiada patut ia berdatang sembah di hadapan raja-raja dengan sembah 
yang dusta. Bahawa laki-laki itu menyumpah Syah Alam dengan kata yang keji, dan sanya perdana menteri itu salah sembahnya,"

Demi/didengar raja sembah menteri itu, lalu ia dukacita, serta ia bersabda, "Bahawa sembah yang dusta itu terbaik daripada sembahmu yang benar. Ada jua pada menteri itu suatu muslihat yang baik dan padamu suatu hasad yang jahat." Lalu ia dimurkakan akan dia.

(Jelani Harun, 2008: 540-542)

Peristiwa tersebut menceritakan seorang perdana menteri yang ingin menjaga kebajikan rajanya dengan suatu muslihat yang baik supaya rajanya mengampunkan kesalahan lelaki tersebut. Namun begitu, terdapat juga wazir yang mempunyai persengketaan dengan perdana menteri tersebut telah menafikan muslihat yang baik oleh perdana menteri. Raja telah murka kepada wazir kerana wazir tersebut mempunyai tujuan yang jahat. Seperti firman Allah SWT;

Ertinya: Bertolong-tolong oleh kamu pada berbuat kebajikan dan takut akan Allah Taala dan jangan kamu bertolong-tolong berbuat dosa dan aniaya.

(Surah al-Ma'idah: 2)

\section{Keadilan Akhlak}

Keadilan akhlak ialah keadilan yang selaras dengan sifat-sifat baik yang tertinggi yang membina satu ukuran kelakuan manusia (Majid Khadduri, 1999: 129). Selaras dengan keadilan undang-undang, maka manusia diperintahkan supaya mematuhi satu ukuran minimum kewajiban. Sementara itu, keadilan akhlak memerlukan manusia untuk mengikut ukuran kebaikan yang tertinggi mungkin. Beberapa pemikir Islam seperti Miskawayh (421/1030) dan al-Razi (505/1111) menjelaskan bahawa keadilan akhlak bukanlah semata-mata satu susunan tanggungjawab agama dan undangundang tetapi juga kewajipan moral atau kecenderungan kepada kebaikan dan keburukan yang harus dipikul oleh manusia sekiranya dia mencari keadilan yang selaras dengan satu ukuran akhlak. Oleh itu, keadilan akhlak merupakan nilai-nilai baik atau positif yang tertanam dalam diri setiap 
manusia. Menerusi naskhah Bustan al-Salatin, keadilan akhlak golongan pembantu raja dapat dilihat melalui beberapa peristiwa. Misalnya;

Syahadan adalah syarat segala wazir itu dua puluh dua syarat. Maka syarat pertama, hendaklah wazir itu takut akan Allah Taala lagi ia perbuat amal salih dan jangan ia berbuat derkaha akan Tuhan sarwa semesta alam sekalian kerana kesukaan rajanya. Seperti kata sahibulhikayat, bahawa adalah bagi sultan [..] anak Sultan/Mahmud Ghaznawi seorang wazirnya bernama Mansur. Adalah sentiasa dihadapkannya dirinya pada tiap-tiap hari sudah sembayang subuh hingga terbit matahari, maka ia bangkit daripada masallanya. Sekali peristiwa, pada suatu hari, lagi terbit matahari, tatkala itu dititahkan sultan takluknya memanggil dia. Maka orang pun pergi memanggil dia. Setelah ia sampai maka dilihatnya ia sembahyang. Maka orang yang memanggil itu pun kembalilah serta ia berdatang sembah, "Ya Tuanku Syah Alam, bahawa Abu Mansur amat sangat besar lakunya, tiadalah dipedulikan Syah Alam memanggil dia." Demi didengar sultan sembahnya, maka ia pun amarah.

Hatta matahari pun terbitlah. Maka Abu Mansur pun segera datang mengadap. Maka sabda sultan serta dengan amarahnya, "Ngapa engkau lambat datang?" Maka sembahnya, "Ya Tuanku Syah Alam, bahawa yang diperhamba ini hamba Allah jua dan seorang daripadanya khadam Syah Alam. Apabila belum pi lagi selesai daripada diperhamba mengerjakan pekerjaan Tuhan yang menjadikan diperhamba maka betapa diperhamba mengerjakan pekerjaan Syah Alam." Demi didengar sultan demikian, maka ia pun menangislah.

(Jelani Harun, 2008: 513-514)

Peristiwa ini menunjukkan seorang wazir yang sangat mentaati perintah Allah SWT. Abu Mansur tetap mengutamakan kewajipannya terhadap Allah SWT walaupun dipanggil oleh rajanya. Hal ini membuktikan Abu Mansur mempunyai akhlak yang tinggi. Akhlak merupakan satu sifat keperibadian yang melahirkan perbuatan manusia dalam membentuk kehidupan yang sempurna berdasarkan prinsip-prinsip yang telah ditetapkan oleh Allah SWT (Tengku Intan Marlina \& Salinah, 2012: 2). Di samping itu, menurut Zuridah Zahir dan Nuwairi (2012), akhlak merangkumi hal yang berkaitan dengan hubungan antara manusia dengan manusia serta 
hubungan manusia dengan pencipta-Nya. Peristiwa yang digambarkan oleh pengarang jelas menunjukkan bahawa wazir Abu Mansur sangat menjaga hubungannya dengan Allah SWT dengan mengutamakan kewajipannya terhadap Allah SWT. Selain itu, keadilan akhlak seseorang pembantu raja dapat dilihat menerusi peristiwa berikut;

Sekali peristiwa, pada suatu hari, Syeikh Abu Bakar berkirim surat kepada anaknya, kadi di negeri [Hastan?], Demikian bunyinya, "Hai anakku, bahawa janganlah engkau menghukumkan antara segala manusia tatkala engkau amarah, maka bahawasanya kudengar sabda Nabi sallallahu alaihi wasallam: La yaqda'l-qadi bain ithnain wa huwa ghadban. Ertinya: Jangan dihukumkan oleh kadi antara dua orang tatkaka amarah."

(Jelani Harun, 2008: 523)

Syeikh Abu Bakar menasihati anaknya yang menjadi kadi supaya tidak memberi hukuman dalam keadaan marah. Hal ini disebabkan sebarang hukuman yang dibuat ketika marah mungkin akan menjadi tidak adil kerana hukuman tersebut diberikan berdasarkan emosi dan bukannya menggunakan akal fikiran. Akal menjadikan manusia berfikir tentang perkara baik dan menghindarkan diri daripada hasutan hawa nafsu. Justeru, akal menjadi tunjang untuk berfikir secara rasional dan waras dan akhirnya melahirkan tindakan yang adil. Kepentingan akal dalam melahirkan manusia yang berlaku adil telah dijelaskan oleh Nuruddin ar-Raniri menerusi naskhah Bustan al-Salatin (Jelani Harun, 2003: 135),

Syahadan nyatalah hikayat ini, barangsiapa ada baginya ilmu sekalipun bahawasanya akalnya itulah menyampaikan dia kepada martabat yang ketinggiannya. Dan barangsiapa ada baginya ilmu dan tiada baginya akal, nescaya kembalilah segala pekerjaannya terbalik. Dan barangsiapa ada baginya sempurna akalnya serta alim, nescaya adalah ia di dalam dunai hakim yang bijaksana lagi ikutan segala manusia. Maka bahawasanya, keelokan dan kemuliaan dan kebesaran martabatnya dan kebajikannya segala hal dunianya dan akhiratnya dengan akal jua. Dan kesempurnaan segala suatu dengan dia jua. Dari kerana akal pohon iman dan pertengahannya dan kesudahannya. 
Nuruddin ar-Raniri mengibaratkan akal dengan pohon iman. Manusia yang tidak berfikir menggambarkan kelemahan pohon imannya, manakala manusia yang berfikir dapat meninggikan martabat kesempurnaan hidup. Oleh itu, akal akan membuahkan kewarasan dalam membuat sesuatu keputusan atau tindakan. Gangguan emosi akan menjejaskan akal untuk berfikir secara rasional. Oleh itu, seseorang kadi haruslah memberi hukuman dalam keadaan yang tenang supaya hukuman yang diberikan adalah adil bagi semua pihak.

\section{Implikasi amalan keadilan dalam sistem pemerintahan sesebuah kerajaan}

Pemerintahan dan kepemimpinan Rasulullah SAW dan Khulafa al-Rasyidin merupakan contoh pemerintahan dan kepemimpinan yang terbaik yang pernah disaksikan dan perlu menjadi ikutan oleh pemerintahan pada zaman seterusnya. Salah satu ciri-ciri yang menonjol dalam pemerintahan dan kepemimpinan Rasulullah SAW dan Khulafa al-Rasyidin adalah keadilan. Keadilan juga merupakan salah satu prinsip asas yang telah diperintahkan oleh Allah SWT dalam al-Quran yang telah diterapkan dalam sistem pemerintahan Rasulullah SAW Berbeza dengan Barat yang menjelaskan bahawa keadilan harus melibatkan dua pihak, misalnya antara masyarakat dan negara atau rakyat dan raja, sebaliknya Islam menggariskan keadilan bermula dan berakhir dalam diri setiap manusia itu sendir (Wan Mohd Nor, 2005: 45; Syed Muhammad Naquib, 2001: 37).

Amalan keadilan telah membawa kesan yang positif dalam sistem pemerintahan sesebuah negara. Antara implikasi yang terhasil kesan daripada amalan keadilan dalam pemerintahan ialah dapat mewujudkan sistem perundangan yang berkesan. Sistem perundangan yang berkesan berteraskan keadilan dan kesaksamaan tanpa mengira perbezaan darjat, status sosial, ekonomi, bangsa dan sebagainya. Orang yang bersalah tetap bersalah dan dikenakan hukuman yang setimpal sekalipun dia merupakan golongan bangsawan dan begitu juga sebaliknya. Rasulullah SAW bersabda yang bermaksud: 
Sesungguhnya telah binasalah umat sebelum kamu kerana apabila golongan bangsawan melakukan kesalahan dia dibebaskan dan apabila golongan bawahan melakukan kesalahan maka dia dikenakan hukuman. Demi Allah kalau Fatimah sekalipun yang mencuri, tangannya akan dipotong.

(Hadis Riyawat Bukhari dan Muslim)

Selaku pemimpin yang adil, Rasulullah SAW sanggup menjatuhkan hukuman yang berat meskipun terhadap anak kandungnya sendiri jika melanggar syariat Allah SWT. Ketegasan seorang pemimpin dalam menegakkan keadilan telah menyebabkan beliau dihormati dan disayangi oleh umatnya.

Seterusnya, amalan keadilan akan membawa kepada kesejahteraan dan keharmonian sesebuah kerajaan. Hal ini terjadi kerana pemerintah yang mengamalkan keadilan akan berkecenderungan untuk sentiasa memelihara keselamatan dan kesejahteraan hidup masyarakat di bawah naungannya. Dengan adanya asas keadilan dalam masyarakat, setiap individu akan berasa aman dan tenteram kerana tugas keadilan ialah memberi jaminan dan keselamatan kepada akal, diri, harta benda, agama dan keturunan manusia. Bukan itu sahaja, pemerintah yang mengamalkan nilai-nilai keadilan dalam setiap amalan kepemimpinannya akan mencapai tingkat dan martabat yang tinggi dan mendapat keberkatan serta keredaan Allah SWT. Justeru, pemimpin atau pemerintah yang mengamalkan keadilan akan membawa manfaat pada dirinya sendiri serta kepada masyarakatnya.

Bukhari al-Jauhari telah memetik beberapa buah hadis dan kata-kata hikmat yang berkaitan dengan beberapa faedah dan kelebihan besar yang akan diperoleh oleh golongan pemerintah yang mengamalkan perbuatan keadilan semasa pemerintahannya sebagaimana yang tergambar dalam petikan berikut.

Pekerjaan dalam kerajaan daripada raja yang adil itu dalam kerajaannya dalam menghukumkan dengan hukum yang adil pada sehari juga terlebih pahala daripada enam puluh tahun sembahyang adanya dan pada hari kiamat beroleh naung Arasy Allah akan naungan raja yang adil.

(Khalid Hussain 1992: 66) 
Petikan daripada kitab Fadhail al-Muluk yang diambil oleh Bukhari al-Jauhai itu menerangkan tentang raja-raja yang berlaku adil akan memperoleh pahala yang berlipat kali ganda (menyamai pahala 60 tahun sembahyangnya). Begitulah ganjaran yang Allah SWT berikan kepada pemimpin yang berlaku adil dalam menjalankan tanggungjawabnya. Pemerintah yang adil akan menerima ganjaran syurga, manakala pemerintah yang zalim akan menerima azab neraka. Oleh hal yang demikian, golongan ini dituntut agar sentiasa berpegang teguh pada prinsip keadilan dan manjauhkan diri daripada melakukan kezaliman.

Golongan pemerintah atau pemimpin yang mengamalkan keadilan akan mengangkat martabat dan darjat bangsa dan kerajaannya. Hal ini disebabkan golongan pemerintah yang bermaruah dan adil merupakan teras kepada pembinaan sebuah negara yang makmur. Tambahan pula, pemimpin atau pemerintah yang menghiasi jiwanya dengan nilai-nilai keadilan secara tidak langsung akan membawa masyarakat dan kerajaannya menuju kehidupan yang lebih sentosa dan harmoni. Sifat keadilan yang tertanam dalam keperibadian setiap golongan pemerintah atau pemimpin merupakan aspek penting dalam mencipta suasana kemasyarakatan yang baik dan sempurna, sekali gus membolehkan sesebuah kerajaan tersebut mendapat perhatian dan dipandang tinggi oleh masyarakat luar.

\section{KESIMPULAN}

Islam merupakan suatu cara hidup yang sempurna telah menyediakan pelbagai ganjaran pahala yang besar kepada golongan pemerintah yang berjaya melaksanakan tugas dan tanggungjawabnya dengan baik, iaitu yang berpegang teguh kepada prinsip keadilan.

Berdasarkan hasil penelitian konsep keadilan oleh golongan pembantu raja dalam naskhah Bustan al-Salatin Bab Ketiga Fasal Kedua, dapat disimpulkan bahawa keadilan tidak terbatas kepada golongan tertentu sahaja, iaitu golongan raja, tetapi perlu ditegakkan oleh golongan lain termasuklah golongan pembantu raja, iaitu wazir dan kadi serta golongan 
masyarakat. Salah satu unsur utama yang sering menjadi peraturan kepada golongan pemerintah adalah berkaitan persoalan keadilan kepada rakyat jelata. Golongan ini mempunyai pelbagai keistimewaan dari segi keturunan, kekayaan harta benda ataupun kekuasaan. Pada masa yang sama, golongan ini juga memegang amanah dan tanggungjawab yang besar terhadap rakyat dan kerajaannya.

\section{RUJUKAN}

Abdullah Sani Usman. (2005). Nilai sastera ketatanegaraan dan undangundang dalam Kanun Syarak Kerajaan Aceh dan Bustanul Salatin. Bangi: Universiti Kebangsaan Malaysia.

Aidil Farina Omar. (2002). Shaykh Nur al-din al-Raniri: A study of his career and Magnum Opus Bustan al-Salatin. Kuala Lumpur: Universiti Islam Antarabangsa Malaysia.

Idris Zakaria \& Mohd Nasir Omar. (2014). Pemikiran politik \& kenegaraan. Jurnal Al-Hikmah, 6 (2): hlm. 108-118.

Jelani Harun. (2001). Kitab kumpulan ringkas berbetulan lekas: Karya ketatanegaraan Melayu terakhir. Pulau Pinang: Universiti Sains Malaysia.

Jelani Harun. (2003). Pemikiran adab ketatanegaraan Kesultanan Melayu. Kuala Lumpur: Dewan Bahasa dan Pustaka.

Jelani Harun. (2004). Pemikiran Melayu tentang keadilan raja: Satu analisis berdasarkan karya adab ketatanegaraan. Dlm. Worawit Baru Haji Ahmad Idris (Pngr.). Pemikiran Melayu Tradisi dan Kesinambungan. Kuala Lumpur: Dewan Bahasa dan Pustaka.

Jelani Harun. (2006). Nasihat al-Muluk:Nasihat kepada raja-raja. Kuala Lumpur: Dewan Bahasa dan Pustaka.

Khairul Azhar Idris. (2007). Keadilan sosial dari perspektif Islam. Kuala Lumpur: MPH Group Publishing Sdn. Bhd.

Khalid M. Hussain. (1992). Taj al-Salatin. Kuala Lumpur: Dewan Bahasa dan Pustaka.

Majid Khadduri. (1994). Konsep keadilan dalam Islam. Kuala Lumpur: Dewan Bahasa dan Pustaka.

Majid Khadduri. (1999). Teologi keadilan perspektif Islam. Surabaya: Risalah Gusti.

Mariam Md. Salleh, Mohammed Sani Ibrahim \& Siti Rahayah Ariffin. (2009). Kepimpinan dan pengurusan di institusi pendidikan MARA. Jurnal Pendidikan Malaysia, 34 (1): hlm. 219-233.

Muhd Norizam Jamian \& Mohd Yuszaidy Mohd Yusoff. (2017). Keadilan teras kepimpinan raja-raja Melayu: Dari era tradisi ke kontemporari. Jurnal Melayu, 16 (1): hlm. 62-80. 
Muzaffar Mohamad \& Suzana Othman. (2003). Melayu Islam beraja menggali hakikat leluhur. Kuala Lumpur: Pustaka BSM Enterprise.

Salmah Jan binti Noor Muhammad. (2006). Transliterasi dan kajian pustaka Melayu dalam Bustan al-Salatin. Tesis untuk memenuhi Keperluan Ijazah Sarjana Sastera, Fakulti Bahasa Moden dan Komunikasi. Universiti Putra Malaysia.

Sayyid Qutub. (1983). Al-Adalah al-Ijitima’iyyah fi al-Islam. Kaherah: Dar alShuruq.

Siti Hawa Haji Salleh (pngr.). (1992). Bustan al-Salatin. Kuala Lumpur: Dewan Bahasa dan Pustaka.

Syed Muhammad Naquib al-Attas. (2001). Risalah untuk kaum Muslimin. Kuala Lumpur: Institut Antarabangsa Pemikiran dan Tamadun Islam.

Tengku Intan Marlina Tengku Mohd. Ali \& Salinah Ja’afar. (2012). Pemerkasaan modal insan: Pembentukan sikap dan akhlak Islamiah dalam novel. Jurnal Melayu, 9: hlm. 55-73.

Wan Mohd Nor Wan Daud. (2005). Falsafah dan amalan pendidikan Islam Syed M. Naquib al-Attas: Satu huraian konsep asli Islamisasi. Kuala Lumpur: Penerbit Universiti Malaya.

Zuraidah Abdullah, Zahir Ahmad \& Nuwairi Khaza'ai. (2012). Pantun ungkapan Melayu sebagai wahana kepimpinan Melayu ke arah pembangunan modal insan. Jurnal Melayu, 9: hlm. 155-170. 
